Kornelija Pinter

kornelijap@net.hr

Sanjin Sorel

sanjin.sorel@xnet.hr

\title{
Ponavljanje, parodija ili raspadanje prazne ploče magijskih performativa u hrvatskome suvremenome pjesništvu
}

\begin{abstract}
Pinter Kornelija, Sorel Sanjin, Ponavljanje, parodija ili raspadanje prazne ploče magijskih performativa u hrvatskome suvremenome pjesništvu (Repetition, Parody or Disintegration of the Empty Plate of Magic Performatives in Croatian Contemporary Poetry). „Poznańskie Studia Slawistyczne” 4. Poznań 2013. Adam Mickiewicz University Press, pp. 139-150. ISBN 978-83-232-2525-6. ISSN 2084-3011.

In the article, from different linguistic and literary theoretical perspectives, parodic function of anaphora is analyzed on samples of Croatian contemporary poetry. The aim is to present how a poem, especially one that is not from the contemporary lyric collection, is not a realization of ,mythic time”, but in its rhythms and structures, where repetition is conditio sine qua non of lyricism, it keeps a trace, a memory of the imaginary, of the myth which in speech revives what is hidden and suppressed.
\end{abstract}

Keywords: parody, repetition, aliteration, myth, Croatian modern poetry

Freud, objašnjavajući regresiju, navodi kako je riječ o razvojnom odnosu u kojemu se složenije strukture određuju putem arhaičnijih i jednostavnijih, o povratku prema prvim objektima ${ }^{1}$, o tome da se ono ja vraća u ranije faze razvitka ${ }^{2}$. Objašnjavajući pseudo uzroke oblika mišljenja, objektnih odnosa i strukturiranosti ponašanja ${ }^{3}$, Freud u topičkom, vremen-

${ }^{1}$ S. Freud, Uvod u psihoanalizu, prev. B. Lorenc, Beograd 1976, str. 319.

2 Ibidem, str. 334.

3 J.-B. Pontalis, J. Laplanche, Rječnik psihoanalize. Regresija, prev. R. Zdjelar, B. Buden, Zagreb 1992, str. 415. 
skom i formalnom smislu objašnjava jednu važnu odliku sna - u snu se misli pojavljuju u slikovnom obliku. Na ovome mjestu ne zanima nas ja subjekta, ni libido, već reverzibilnost, regresivni odnos jedne složene književne činjenice prema istoj, no znatno jednostavnijoj. U anafori, zapravo, nema ničega složenog. No kada se ona nađe u obliku parodije ili eufonijske pjesme, tada poprima metatekstualni oblik te preuzima konotativne funkcije ironije, groteske, parodije, humora. Anafora je jedna u nizu figura ponavljanja, a uz epiforu i najuočljivija. Ne samo da određuje početak stiha nego pjesmu ritmički i melodijski intonira i još nešto - u nekim slučajevima posebno naglašava upravo sebe, anaforičku riječ ili sintagmu koja je u njezinoj funkciji.

Iz kognitivnolingvističke perspektive ja subjekta nas itekako zanima, jer nam objašnjava odnos magična riječ - molitva u vizuri intencionalnosti i djelotvorne moći u književnome tekstu. Kako, pokušat ćemo prikazati u nastavku. Svakodnevna jezična komunikacija ovisna je, u smislu svoje učinkovitosti, o konstantnom nadopunjavanju (sustava) predodžbi (o predmetima i o pojavama). Jezik misli/neverbalni jezik izvor je naših verbalnih zaliha. Kakve će biti predodžbe i koliko ce ih biti ovisi o interakciji sa svijetom oko nas. Povratna informacija o iskustvu organizma formira se u sustav predodžbi, podvrgava značenjskome procesuiranju, potom se predodžbe prevode u pojmove, a pojmovi u jezik. Ono što se u našem organizmu događa slijedom konstantnih interakcija s okolinom, stvaranja sustava predodžbi, značenjskog procesuiranja i konačno verbalizacije, proces je razvoja svijesti o nama samima. Unos i preinake, nadopune predodžbi konstantne su, ne bi li naš doživljaj svijeta i nas samih bio jasniji, razgranatiji, sveobuhvatniji, protočniji u svojoj cirkularnosti. Ja se konstantno kreira u silini pritiska dohvaćanja i konstruiranja slike svijeta, posredstvom tijela kao spužve koja posjeduje složene mehanizme preoznačavanja i verbalizacije $^{4}$. Slijedom toga verbalizacija je zrcaljenje naših tjelesnih i men-

4 ,Jezik se misli - neverbalni jezik, mentalni jezik - u neuroznanosti povezuje s procesom osvještavanja čovjekova ja, s nastajanjem svijesti jedinke o samoj sebi. Taj je proces, suprotno prividu njegove dovršenosti koji vezujemo uz pojam sazrijevanja ljudske jedinke, kontinuiran i uvijek nedovršen; uspostavljanje temelja svjesnoga djelovanja povezano je $\mathrm{s}$ neprestanim, cjeloživotnim previranjima u samoj jezgri. U simulatanu, interferentnom, nemalim dijelom i kolidirajućem suodnosu svjesnog i nesvjesnog, ja se kreira i konstantno rekreira kao mentalno osviješten izvod vlastita tjelesnoga prototipa (proto-ja) koji u suodno- 
talnih iskustava usklađenih sa spoznajnim aspiracijama, ona je preslika (jednoga dijela) našega neverbalnog svijeta, svijeta viđenog očima subjekta. Jezik svakodnevne komunikacije, kao što smo prethodno pokušali prikazati, određen je konstantnim nadopunjavanjem predodžbi u mentalnome jeziku. Iako u stalnoj mijeni, taj je jezik konvencionaliziran, definiran, ograničen, a mijena mu je podložna tempu jezične zajednice. Nasuprot jeziku svakodnevne komunikacije literarni jezik prelazi rubove, standarde i definicije poznatoga i opisanog svijeta i jezika tog svijeta, da bi otvorio prostor kreativnome mišljenju, mimetičnosti, metaforičnosti, novim spoznajama. Milorad Stojević je u pjesmi Molitva da bude bilo više smisla, ili: Bar micva u Hatzeovoj 25 odabrao formu molitve navodeći nas na sličnost sa stvarnim svijetom ${ }^{5}$, međutim ovdje se radi o literarnoj mimetičnosti koja koristi našu prvotnu predodžbu pojma molitve, a potom je prilagođava osobnoj, nadstvarnosnoj literarnoj logici te nas snagom svoje suverene stilizacije poziva da posegnemo u jezik mišljenja, dublji, neverbalni jezik, da potaknemo svoju autoreferencijalnu i metajezičnu poziciju. Iako je lirski subjekt doista rezigniran, obeshrabren, navodi nas da citamo po tradicionalnom, prepoznatljivom, bogobojaznom ključu, ipak njegovo obraćanje Bogu na mnogim je mjestima izravno nihilističko, ateističko, sarkastično i humoristično, čime nas uvodi u prostore i odnose odabrane po vlastitome literarnom rješenju, prostore pjesme u kojima vlada kohezivna nutarnja sila.

Ujedno je riječ i o odnosu intertekstualnosti, odnosu gdje derridijanski pojam traga nesumnjivo igra ulogu užitka, onoga užitka kojega Roland Barthes zaziva u odnosu između čitljivog i ispisivog teksta, između zadovoljstva i izazivanja povijesnih, kulturnih i psihologijskih pretpostavki ${ }^{6}$.

su sa svijetom prepoznaje sebe tragovima promjena koje mu takav odnos nanosi”. M. Biti, O suodnosu mentalnih i jezičnih svjetova iz perspektive kognitivne stilistike, „Fluminensia: časopis za filološka istraživanja" br. 19, 2007, str. 54.

5 ,Jezični znak opisuje vanjski svijet nastojeći što manje nalikovati tom svijetu, jer se tako postiže efikasnost komunikacije: jer se tek tako oblikuje kreativni govor, kojim se izražavaju misli, kojim se opisuje i interpretira, a ne samo imitira stvarnost. Pjesnički znak stvara svoj vlastiti svijet nastojeći što više nalikovati svom kontekstu, tj. nastojeći uspostaviti što više materijalnih veza sa svojim kontekstom”. B. Vuletić, Fonetika pjesme, Zagreb 2005, str. 100.

${ }^{6}$ R. Barthes, $S / Z$, Paris 1970. 
Ivo Pranjković na jednome mjestu kaže da stilske figure nastaju postupkom kao što je ponavljanje: ,ponavljanje (repeticija, reduplikacija) pojedinih jezičnih elemenata, može se ticati i fonološke (odnosno fonetske) i morfološke i sintaktičke te, osobito često, suprasintaktičke razine, tj. razine teksta"7. U pjesmama zaumskoga tipa, a koje u sebi sadrže i elemente dječjih brojalica, Ivan Rogić Nehajev od glasovnih serija, vrlo ritmiziranih, poigrava se unutrašnjom ritmomelodijskom i semantičkom strukturom pjesme. Sasvim je jasno da ponavljanje monotonizira ritam te da se u malim varijacijama on pokreće. Jagoda Zamoda, u knjizi Kaseta „evo; ta!" već i u naslovnoj sintagmi detektira intermedijalnu dimenziju riječi. A ponavlja gotovo sve - riječ, sintagmu, sliku, značenje. Ogoljujući pjesnički izraz vlastitom gramatikalnošću, zapravo, ogoljuje svijet na kategorijalne činjenice, odnosno govori o njegovoj krizi. Hladna katalogizacija svijeta s reduciranim emotivnim registrima subjekta analogna je ponavljajućim gramatičkim i stilskim obrascima kojima se koristi, štoviše njima je potencirana te u Zamodinu pjesništvu ima funkciju dekonstrukcije svijeta jer razobličava njegovu statičnu dubinsku strukturu.

No ponavljanje ima još poneku ulogu u pjesništvu, prije svega kohezijsku. Dvije su vrste kohezije. Prva je gramatička, koja se poziva na strukturu sadržaja, dok se druga, leksička kohezija odnosi na povezivanje sadržaja unutar teksta. Kristina Štrkalj Despot u članku Tekstna kohezija u hrvatskoj srednjovjekovnoj drami, apostrofirajući Kirsten Malmkjær, govori kako se ,unutrašnja (ustrojstvena) kohezija teksta postiže na tri načina: referiranjem, junkcijom i leksičko-sintaktičkim elementima"8. Ponavljanje, paralelizam, sinonimija itd. imaju kohezijsku funkciju u tekstu, dok je anafori u tekstu namijenjena uloga paralelnosti jer u njoj sljedeća rečenica ne proizlazi iz prethodne, kako je to inače u linearnim vezama.

Parodija je intertekstualni postupak. Stavljajući aluziju u prvi plan ona u sebe uključuje mnoge druge kulturne prakse - ironiju, burlesku, oponašanje, humor i sl. Njoj je karakterističan satiričan učinak prema repre-

${ }^{7}$ I. Pranjković, Stilske figure i gramatika, <http://www.hrvatskiplus.org/prilozi/dokumenti/anagram/Pranjkovic_Stilske.pdf>, 23.08.2012, str. 3/11.

${ }^{8}$ K. Štrkalj Despot, Tekstna kohezija u hrvatskoj srednjovjekovnoj drami, ,Croatica et Slavica Iadertina" vol. IV, 2008, str. 66. 
zentacijskim praksama ${ }^{9}$. Ona je konceptualna domena o čijoj smo svrsi već govorili. No da bi njezina svrha bila prepoznata, ona se mora temeljiti na ponavljanjima više ili manje konvencionaliziranih metafora. U našem slučaju ulogu konceptualnih metafora preuzimaju anafore i s njima, kao klasičnim retoričkim figurama, prestaje svaka ustaljenost, barem na primjerima koje uzimamo paradigmatskima. Iskustveno, čitateljsko nam utemeljenje/ukotvljenje govori da se anafora nalazi na početku stiha te da je ona zaslužna za točno određenu vrstu ritmičnosti. Problem nastaje kada ju promatramo kao motivirajući i/ili motivirani element stiha, odnosno kada njezina semantička vrijednost nadilazi uske formativne, stilske razine. Drugim riječima, jednostavna se retoričko-semantička domena komplicira svojim znatno složenijim semantičkim učincima. Sljedeći Kövecsesov model preslikavanja Mateusz Milan Stanojević rezimira kako se ,jedna izvorna domena može rabiti u kombinaciji s nekoliko ciljnih domena, ali zamjećuje da se iz izvorne domene svaki put preslikava isti dio. Taj dio temelji se na središnjem znanju, koje dovodi do središnjih preslikavanja u različitim metaforama" ${ }^{\prime 1}$. U Stojevićevoj je pjesmi izvorna semantička domena Bog, kod Rogića onomatopeje i/ili zaum blja/blje/bljč te $\mathbf{b} / \mathbf{r m}$, kod Sime Mraovića prsten ${ }^{11}$, kod Branimira Bošnjaka pak je vrtlar (Vrtlar, Sječivo za nevine), kod Jagode Zamode količina (Oko usta i oko očiju, Kaseta „evo; - ta!”), kod Ervina Jahića subjekt (Svagdanja deziluzija, Oko andaluzijskog psa), kod Ozrena Prohića arkadija (Arkadija, Pjesni referencijalne). Sve se one koriste kako bi se konvencionalizirano znanje $^{12}$ preslikalo na ciljnu domenu, a potom iz nje konceptualizirala parodija. Budući da se u književnosti, za njezino razumijevanje, čini bitnim središnje znanje o konceptu, jer nam ono pomaže ili odmaže prilikom interpretacije $^{13}$, možemo zaključiti kako većina pjesnika, osim Ivana Rogića Nehajeva, u najvećoj mjeri barata metaforičkim konvencijama - semantika

\footnotetext{
${ }^{9}$ H. Bertens, The Idea of the Postmodern, London-New York 1995, str. 157.

${ }^{10}$ M.M. Stanojević, Konceptualna metafora u kognitivnoj lingvistici: pregled pojmova, „Suvremena lingvistika” br. 68, 2009, str. 350.

11 „U kalupu taj prsten od zlata. U kalupu taj prsten od srebra. / U kalupu taj prsten od vode. / U kalupu taj prsten od zraka”. S. Mraović, Između usana, Zagreb 1997, str. 73.

${ }^{12}$ Znanje o ulozi anafore u stihu i strofi te znanje o apostrofiranim središnjim semantičkim pojmovima.

${ }^{13}$ M.M. Stanojević, op. cit., str. 352.
} 
je prozirna kao i unutarnja motivacija. To je ono što kao čitatelji bez većih problema možemo vidjeti i razumjeti. Problem međutim nastaje kada u parodijskome ponavljanju prepoznajemo i neke performativne učinke.

Dakle parodijski je učinak, bahtinovski rečeno - karnevalski. U postmodernističkoj literaturi tu je karakteristiku ponajbolje opisao Ihab Hassan. Primjerice sučeljavanjem visokih i niskih modusa, Boga i Johnyja Štulića (Molitva..., Milorad Stojević), perfekta pom. gl. biti - bilo izvedenog iz imena pisca (Bilopavlović) te ispijanja (PODiPOSTpredsjednička postpoema za mrtve pa žive, Tahir Mujičić), psihologije subjekta pjesme i popularne kulture (Svagdanja deziluzija, Ervin Jahić), pjesništva i zaumne, onomatopeične besmislice (Paranoya - terapeutica, Ivan Rogić Nehajev) $\mathrm{u}$ različitim se nijansama i intenzitetima humor koristi u agonističkoj funkciji, kao što je i Huizinga umjetnost kao igru gledao u tom svjetlu. Socijalna i žanrovska funkcija parodije u navedenim je tekstovima paradigmatska $^{14}$, karnevaličnost funkcionira samo na manifestnoj razini teksta. Humor je nezaobilazni element parodije. Štoviše, u parodiji je riječ o deductio ad absurdum gdje se namjera neke, u ovome slučaju literarne, karakteristike dovodi do suprotnosti, nonsensa, besmislice. Ta je razina parodije izrazito i jedino manifestna, fenotipska.

Postavlja nam se, opet, sljedeće pitanje - ukoliko je ritualni i magijski čin zbog svoje ponovljivosti ujedno zavodljiv i trans/supstancijalan, može li anaforična parodija također biti zavodljiva? Budući da se koristi humorom, što je antinomijski parnjak ritualu kojega karakterizira vrlo ozbiljno vjerovanje u činove kojima se služi, parodija često ostavlja dojam dosjetke, slamnigovskog ${ }^{15}$ lakog stiha, neobvezujuće igre i humora $\mathrm{i}$, zapravo, to su njezini virusi trojanci kojima se involvira u svijest čitatelja. Želimo reći sljedeće - anaforičkome ponavljanju performativni je učinak prepoznatljiv, barem u analiziranome korpusu i djelomično, naravno, u moći da putem parodije proizvodi ideje kao što su humor, karnevalizacija, satira, subverzivnost, ironija, imitacija te da one prema recipijentima sudjeluju u lancu utjecaja.

\footnotetext{
${ }^{14} \mathrm{U}$ kontekstualnoj aluziji parodijski učinak je sve samo ne duhoviti i humorističan, on detektira neke od latentnih nuspojava tzv. hrvatske društvene tranzicije - vjersku licemjernost, spektakličnost i površnost hrvatske kulture, poročnost, identitetsku nesigurnost.

${ }^{15}$ Namjerno ispuštamo iz analize pjesništvo poete ludensa Ivana Slamniga ne iz razloga što ne odgovara temi, već upravo suprotno - previše joj odgovara stoga bi tekst o njegovu parodijskom diskurzu u sklopu djelotvornosti logosa zauzeo i previše prostora.
} 
Krenimo od očitoga, od onoga što molitva ne bi trebala biti i što molitva ne bi trebala značiti. Mehaničke su one molitve koje se izriču čitanjem, a koje su zapisane u različitim evenđeljima ili ih vjernici znaju napamet, a što, valja napomenuti, čak i Isus u Matejevu evanđelju zabranjuje. Vjernici izgovaraju molitvu vjernika u kojoj traže izravnu Božju pomoć. One započinju invokacijom Boga, Gospodina, Isusa, Marije i sl. ili nakon njihova dozivanja počinju s kakvim performativnim zahtjevom (operi me, učini me, prekrij me) ${ }^{16}$. Ponavljanje je u molitvi bitan dio strukture, primjerice u 136. psalmu litanijski se zazivi 26 puta ponavljaju (kao i u krunici Zdravo Marijo), stoga je riječ o istinskom obraćanju i približavanju Bogu, a ne ispraznom nizanju molbi. Molitva je dio ritualnog obreda, redovito služi nekom tipu poboljšanja. Molitva je ritual strasti i patnje ${ }^{17}$ čije je značenje performativno jer, upućuje nas J. Hillis Miller, govorni činovi djeluju magijski ${ }^{18}$. Ritualni govor je molitva u sadašnjosti ${ }^{19}$, bez obzira da li je sadržaj primaran ili sekundaran. Spomenut ćemo Katičićeve zaključke komparativne analize slavenskih ispovjednih molitava s tekstovima grčke retoričke proze i grčkim ispovjednim molitvama Simeona Metafrasta i Nikefora Kalista. Analiziran je tekst jedne staroslavenske ispovjedne molitve nađene u papirnatom ćirilskom kodeksu br. 1318 Gradske biblioteke u Wrocławu koji potječe iz 14. st. Jezik molitve pokazuje tragove bugarske i srpske redakcije, sastoji se od tri dijela: skrušenost, samooptuživanje i molba za oproštenje (prvih 14 redaka); nabrajanje grijeha; priznavanje svoje grešnosti i molba za oproštenje (posljednjih 17 redaka). Ta je staroslavenska molitva interesantan primjer unošenja stilskih sredstava grčke

${ }^{16}$ Molitva: „Milosrdni Isuse, (...) operi me od grijeha i krivnje svojom dragocjenom Krvlju koju si za me prolio na križu. Ne otjeraj me u srdžbi iz Tvoje prisutnosti. Smiluj mi se Gospodine kao što si se smilovao dobrom razbojniku i ženi javnoj grešnici. Učini me svojim djetetom. Prekrij me svojom dragocjenom Krvlju", <http://www.molitve.info/index.php/ 20080924668/Molitva-za-ozdravljenje.html>, 12.09.2012.

${ }^{17}$ Za primijetiti nam je da i parodija kao žanr ovisi o patosu kao trpnom stanju. Cf. E. Hvorost'janova, Književna parodija kao književnost, u: Mistifikacija/Parodija - Zagrebački pojmovnik kulture 20. stoljeća, ur. S. Ludvig, A. Flaker, Zagreb 2002, str. 242.

${ }^{18}$ J. Hillis Miller, Speech Acts in Literature, Stanford-California 2001, str. 182.

${ }^{19}$ G. Čupković, Ritualni govor i srednjovjekovni dualizam na primjeru jednoga glagoljskog zapisa, „Umjetnost riječi” br. 4, 2006, str. 317. 
retorike, ali u slavenskoj verziji korištenih na drugačiji način ${ }^{20}$. Radi se o nizanju riječi istoga završetka, figuri grčke retoričke proze, izokoliji s homoioteleutima, kojom se postizala „gramatička rima”, a koja se koristila u starim antičkim formama za označavanje vrhunca patosa u tekstu ispovjedne molitve ili retoričkoj prozi, dočim se u slavenskim formama taj stilski element nije koristio za intenzivaciju, već je kao osnovni formalni element složene tekstne strukture vodio $\mathrm{k}$ vrhuncu. Stilske figure nizanja riječi iste tvorbe, istog gramatičkog oblika i sličnog završetka, koje su u antičkim tekstovima imale svoju određenu funkciju i način upotrebe, istrgnute su iz svoga vremena i dobile novu stilsku koncepciju, novu funkciju u slavenskim ispovjednim molitvama s namjerom da izraze nepodnošljivu težinu tereta nesretnoga grešnika. Baš kao što je tvorac slavenske forme za ispovjedne molitve preinačio funkciju antičke stilske retoričke figure homoioteleuta (promijenio, s nerazumijevanjem, nesvjesno deformirao osnovnu stilsku koncepciju grčkih ispovjednih molitava) i Milorad Stojević je u formi kršćanske molitve našao (podatljiv) oblik za stilski pomak u osobnoj redakciji. Svoju je artificijelnu tvorevinu lirskim pravcem preusmjerio iz prostora prepoznatljive kršćanske tradicije u vlastiti medij u kojem literarnim kodom upućuje na mimetičnost pjesničkoga prostora i vlastitu poetičku vjeroispovijest. U pjesmi Milorada Stojevića Molitva da bude bilo više Smisla, ili: Bar micva u Hatzeovoj 25 molitva zadržava svoj ritualni karakter, Gospodin se ponavljajuće zaziva riječju Bože, ipak se taj tekst molitvenim diskurzom ne služi u ritualne svrhe, premda njegovu strukturu iskorištava:

Bože, uznastoj da u mojoj poeziji bude više smisla;

Bože, usrdno Te molim da sve ono što tražim ne bude nađeno;

Bože, naredi mi duhom Svojim da deluzije ne budu to što jesu;

Bože, iako si persiflaža bogova prijašnjih, učini da moje pjesme ne izručuju isti postupak Postanja;

$(\ldots)$

Bože, očaraj one koji u rastrojstvu Smisla ne vide smisao koji obnavlja poeziju;

${ }^{20}$ Katičić ovdje spominje, parafrazirajući Preloga, kako se takav postupak smatrao aktivnom negacijom antike. 
(...)

Bože, vrati vrijeme u doba Kristobala Kolumba i zapali njegove nepotrebne galije;

Bože ubij Niela Armstronga u majčinoj utrobi kako njegov koračić ne bi odjeknuo u ionako neodječnoj atmosferi Mjeseca, Zemljina Mjeseca;

(...).

Vokativ Bože moguće je protumačiti sinegdohalnim prijenosom značenja čitave pjesme na njezin anaforički dio. Riječ Bože ponavlja se 84 puta, takvim se ponavljanjem, parafrazirajući B. Vuletića ${ }^{21}$, stvara zatvoreni prostor, prostor pjesme, a ono je, uz blizinu, osnovno načelo građenja pjesničkoga teksta. „Ponavljanje je i ishodište motiviranosti pjesničkog znaka"22, ponavljanje uvijek upućuje na nešto. Govoreći o glasovnim vezama unutar pjesničkoga teksta Vuletić ističe: „osnovni i uvijek prisutan sadržaj glasovnih veza ostvarivanje je unutarnje motiviranih odnosa među riječima jednakog ili sličnog glasovnog sastava. Značajka unutarnje motiviranosti je povezivanje, poistovjećivanje različitih sadržaja preko jednakog, djelomično jednakog ili sličnog glasovnog sastava" ${ }^{, 23}$.

Vokativ ovdje nosi svoju invokacijsku primarnu funkciju, no je li to njegova jedina uloga u ovom zatvorenom prostoru tijela pjesme? Vokativ ima i ekspresivnu, izražavanje osjećaja i stava prema sugovorniku, komunikacijsku te konativnu (apelativnu) funkciju - jezičnim sredstvima vokativom i imperativom nastoji se izazvati reakcija sugovornika. Stojević izražava svoje osjećaje, nastoji isprovocirati svog sugovornika - Boga, izazvati njegovu reakciju. Međutim parodijom (čiji je performativni učinak polemika), koju nameće kao temeljno raspoloženje pjesme, kazuje kako sugovornik šuti, odbija komunicirati, ne čuje njegove molitve i, ponavljajući pjesmu još jedanput, upućuje nas na eho kojim uzvraća ječna praznina, na prazno mjesto njegova sugovornika.

Temeljni postupak je imitacija, baš kao i u Sto najvećih rupa Ivana Kušana. Ona može imati prema svome predlošku ambivalentan odnos biti afirmativna, kada prema imitiranome tekstu nastupa kao prema uzor-

\footnotetext{
${ }^{21}$ B. Vuletić, op. cit.

${ }^{22}$ Ibidem, str. 101.

${ }^{23}$ Ibidem.
} 
nome, vrijednome, kanonskome ili pak biti parodija, u tom ga slučaju na različite načine karnevalizira i difamira. Imitacija je usto vrsta ponavljanja. Kod nje je riječ o različitim stupnjevima, gradacijama u činu ponavljanja, ne ponavljaju se elementi nego totaliteti tako da parodiju prepoznajemo upravo zbog razlike u stupnjevima ${ }^{24}$, u intenciji. Time, kako navodi Deleuze, ponavljanje dijeli razlika s dva lica - ,ona sinteza vremena dva aspekta: jedno lice, Habitus, okrenuto je prvom ponavljanju koje čini mogućim; drugo se lice, Mnemozina, nudi drugom ponavljanju iz kojeg proističe" ${ }^{, 25}$. Svaki ritualni govor, od kletve do molitve, sastoji se od serijalnog ponavljanja riječi i/ili sintagmi. Ponavljanje, toliko karakteristično za liriku, prvotno je imalo mnemotehničku funkciju. Imitacija je u nekim slučajevima vrsta parodijskoga ponavljanja koja se prerušava i premješta. Umjetničkim, književnim, pjesničkim ponavljanjem prenosi se uvijek neka prošlost, Stojeviću je to ritualni aspekt molitve i Ideja vjere same. Molitva se sastoji od horizontalnog, sintagmatskog paralelizma dok je imitacija vertikalna, paradigmatska, u onim situacijama kada joj je objekt zadan kakvim pravilom. Stereotipnostima, ispražnjenim sadržajima molitvi, Stojević pridaje kreacionističku moć jezika - igru s njime, riječ je o ponavljanju rastemeljenja $^{26}$. Dekonstruira se sama ideja da se molitvom može utjecati na zdravlje, sreću, ljubav, mir. Desupstancijalizirana od svoje temeljne sakralne ideje postaje predmet profane igre. U tom raskoraku, cijepu, u kojemu se još uvijek može prepoznati arhajsko vrijeme koje vjeruje u iscjeliteljsku moć zaziva i riječi, čiji su performativi osiguravali sreću, utjehu, mir te vremena koje na svijet više ne gleda kao praznu ploču ${ }^{27}$, govorni čin prepoznaje svoje mjesto u igri, zabavi, duhovitosti, imaginaciji - u parodiji, kao zajedničkom nazivniku reaktualiziranja ideje slobode ne samo od vjerskih nego i državno-društvenih ideologija. Parodija je svojevrsna poetička politika. Odražava skupove ideja i vrijednosti prema parodiranome/referiranome predlošku i njihovim doslovnim i/ili konotacijskim poljima.

Kod molitve je, i njezine parodije, više ili manje sve jasno o ritualizirajućim funkcijama. No kod anafora koje se u iste svrhe koriste zaumom

${ }^{24}$ Ž. Delez, Razlika i ponavljanje, prev. I. Milenković, Beograd 2009, str. 456.

${ }^{25}$ Ibidem, str. 457.

${ }^{26}$ Ibidem, str. 466.

${ }^{27}$ S. Pinker, Prazna ploča, moderno poricanje ljudske prirode, prev. M. Gračanin, M. Čičin-Šain, Zagreb 2007. 
i/ili onomatopejom nema neke bitnije razlike, osim što se u prvi plan stavlja eufonija. Riječ je o pokušaju karakterističnom za pjesništvo da se jezikom dođe do neiskazivoga, onoga što izmiče spoznaji. Ukoliko je ritual za Claudea Lévi-Straussa povlaštena igra ${ }^{28}$, utoliko je onda pjesništvo koje se koristi navedenim tehnikama ${ }^{29}$ zvučnosti, repeticije, tajnog jezika, brojalica i sl. ono što Donat naziva aktualizacijom zvukovnog simbolizma. Ili drukčije - pokušaj, utopijski, da se jezična ekspresivnost dovede do krajnjih konzekvenci. Magijske su to prakse utemeljene na glosolaliji. Michael Suk-Young Chwe kaže kako je svrha rituala tvorba zajedničkog znanja radi socijalne interakcije ${ }^{30}$. Kroz rituale se osnažuju pravila ponašanja. Naglašava kako je pjesma pogodna za ritual jer je njezina važna strukturna karakteristika ponavljanje, ali i zalihost, ograničavanje polisemije, sigurnost putem govorne formalizacije, simbolizacija, zajedništvo, tj. dramatično jedinstvo $^{31}$. Slično kažu i Abraham Rosman, Paula G. Rubel i Maxine Weisgrau - ritual uključuje sudioništvo u radnjama i govoru koji mijenjaju emotivno stanje sudionika. U njima do izražaja dolaze socijalne interakcije, komunikacije i dijeljenje simboličkih vrijednosti ${ }^{32}$. Time se i naoko radikalni pjesnički iskazi pokazuju u svjetlu regeneracije pjesništva. Stoga kada se jedan smjer tumačenja glosolalijskoga ponavljanja, zauma i sl. tumači u svjetlu parodije, onda je i opet riječ o obnavljanju. Da je jedna od uloga parodije i obrana pjesništva samog, njegove vrijednosti, stila, funkcije i sl. utvrdio je i Simon Dentith ${ }^{33}$. Čini nam se točnim ono što je zaključila Elena Hvorost'janova da je parodija naglašeno povijesni žanr. Njezina funkcija prepoznaje se i u tome da, od na prvi pogled negativnih atribucija (subverzivnost, nonsens i sl.) u razdobljima književne stagnacije, neinventivnosti, krize, relativizacije i iscrpljenja ulazi na ispražnjeno mjesto te postaje uočljivijom i važnijom, raznolikijom i istančanijom ${ }^{34}$, zapravo, ono

${ }^{28}$ K. Levi-Stros, Divlja misao, prev. J. i B. Jelić, Beograd 1978, str. 72.

${ }^{29}$ B. Donat, Poezija i jezične utopije, u: idem, Pegaz ili dada, Rijeka 1988.

${ }^{30}$ M. Suk-Young Chwe, Rational Ritual: Culture, Coordination, and Common Knowledge, New Jersey 2001, str. 26.

${ }^{31}$ Ibidem, str. 28-30.

${ }^{32}$ A. Rosman, P.G. Rubel, M. Weisgrau, The Tapestry of Culture. An Introduction to Cultural Anthropology, Lanham 2009, str. 238.

${ }^{33}$ S. Dentith, Parody, London-New York 2000, str. 97.

${ }^{34}$ E. Hvorost'janova, op. cit., str. 242. 
što je duhovito Milorad Stojević rekao u jednom intervjuu - a to je da se vidi u ulozi kalafata, majstora koji rupe u drvenim brodovima krpa/začepljuje smolom. Ne moramo posebno niti napomenuti da su ti majstori u odumiranju, baš kao i drveni brodovi.

\section{4}

U nekom su trenutku u mitu riječi i stvari bile neodvojive ${ }^{35}$. Danas mit više nema tu djelotvornu snagu osim da se služimo njegovim transformiranim rubovima koji obuhvaćaju znanje i vjerovanje, time stvarnost i fikciju. Pjesma, pogotovo ne iz fundusa suvremene lirike, nije realizacija „mitskoga vremena", ali u svojim ritmovima i strukturama, gdje je ponavljanje conditio sine qua non pjesmovnosti/liričnosti, čuva trag, pamćenje na imaginarno, na mit koji u govoru oživljuje potisnuto i skriveno. Zagonetnost mita iskazuje se u nesvjesnom pjesme. Stoga ne čudi što je Albert Cook u nadrealističkoj pjesmi vidio vraćanje, regresiju jezika prema mitu. Ili što autori poput Milorada Stojevića u navedenoj pjesmi ili pak u eufonijskoj varijanti Ivan Rogić Nehajev u pjesmi 2. stavak: Z-vuk referiraju na božanski mit o logosu i njegovu zaumnom prajeziku. Na tragu zaključka da se Stojević, obraćajući se Bogu, ustvari obraća tišini, nikome, praznini, ili svima i svemu, ostaje pitanje, obraća li se sebi, svojoj vlastitoj prirodi? Ili, zerzanovski ${ }^{36}$ rečeno, uslijed silnih postmodernističkih nadbogivanja s prirodom, povratak prirodi možda je jedina opcija postojanja.

${ }^{35}$ A. Kuk, Mit i jezik, prev. D. Puhalo, Beograd 1986, str. 306.

${ }^{36}$ J. Zerzan, Anarhoprimitivizam protiv civilizacije, prev. V. Kirinić, I. Grbić, Zagreb 2004. 